\title{
OBLIGACJE KOMUNALNE NA RYNKU CATALYST W LATACH 2011-2015
}

\section{WPROWADZENIE}

Jednostki samorzadu terytorialnego (JST) w Polsce zostały prawnie zobligowane do realizacji określonych zadań, na których wykonanie wyposażone zostały przez ustawodawcę w odpowiednie środki - dochody. Zaspokojenie potrzeb wspólnoty lokalnej wymaga jednak znacznych nakładów, które niejednokrotnie przewyższają możliwości finansowe samorządów, co przyczynia się do zmuszenia ich do braku równowagi budżetowej, a co za tym idzie, poszukiwania dodatkowych źródeł finansowania. Dlatego też w art. 89 ustawy o finansach publicznych ${ }^{1}$ wskazano na możliwość zaciagania kredytów i pożyczek oraz emitowania papierów wartościowych przez JST.

Zamieszczając wskazany zapis, ustawodawca ustanowił podstawę prawna do zaciagania zobowiązań przez JST w celu finansowania m.in. długu jednostki, wskazując jednocześnie na emisję papierów wartościowych jako jeden z dopuszczalnych instrumentów równoważenia budżetu oraz zapewnienia płynności finansowej zarówno w krótkim (przejściowy deficyt), jak i długim okresie (spłata wcześniej zaciagniętych zobowiązań, planowany deficyt itp.).

JST chcące pozyskać kapitał bezpośrednio na rynku mogą emitować papiery wartościowe w formie obligacji. Powstały w 2009 r. system obrotu dłużnymi instrumentami finansowymi Catalyst umożliwia samorządom - emitentom - plasowanie emisji na rynku regulowanym oraz alternatywnym, oferując jednocześnie szerokie spektrum korzyści wynikających z obecności na nim, tj. łatwiejszy dostęp do kapitału, budowanie wiarygodności czy promowanie jednostki².

Celem niniejszego artykułu jest analiza rynku obligacji komunalnych jako prawnie dozwolonego instrumentu finansowania jednostki samorzą du terytorialnego, ze szczególnym uwzględnieniem sytuacji na rynku obrotu dłużnymi papierami wartościowymi JST w latach 2011-2015.

\footnotetext{
${ }^{1}$ Ustawa z 27 sierpnia 2009 r. o finansach publicznych, Dz. U. 2009, Nr 157, poz. 1240 (dalej jako: u.o.f.p.).

${ }^{2}$ S. Huczek, Przewodnik dla potencjalnych emitentów. Obligacje komunalne na rynku Catalyst, Oficjalne Wydawnictwo Giełdy Papierów Wartościowych, Warszawa 2010, s. 15-16.
} 


\section{OBLIGACJE KOMUNALNE ${ }^{3}$ JAKO ŹRÓDŁO FINANSOWANIA JEDNOSTEK SAMORZĄDU TERYTORIALNEGO}

Chcąc mówić o obligacjach komunalnych jako instrumencie finansowania zadłużenia JST, należy uprzednio określić znaczenie pojęcia obligacji w świetle obowiązujących przepisów prawa. Ustawa o obligacjach nie wprowadza prawnej definicji obligacji komunalnych. Należy jednak przyjać, że termin ten jest zbieżny z zapisem art. 4 ust. 1 ustawy o obligacjach ${ }^{4}$, stanowiącym, iż obligacja jest emitowanym w serii papierem wartościowym, w którym emitent stwierdza, iż jest dłużnikiem właściciela obligacji (obligatariusza), i zobowiąuje się wobec niego do spełnienia określonego świadczenia $^{5}$. Pragnąc jednak ww. ogólną definicję obligacji przenieść na grunt samorządowy, należy wskazać na osobę emitenta jako charakterystyczny element obligacji komunalnej. Zatem zgodnie $\mathrm{z}$ art. 2 ust. 5 ustawy o obligacjach ustawodawca określa gminy, powiaty oraz województwa, a także związi tych jednostek jako podmioty uprawnione do emitowania obligacji. $\mathrm{Na}$ tej podstawie obligację komunalna zdefiniować można jako emitowany w serii papier wartościowy, w którym JST lub ich związek oświadcza, że jest dłużnikiem właściciela obligacji i zobowiązuje się wobec niego do spełnienia określonego świadczenia.

Analizując wartość rynku obligacji komunalnych w Polsce w latach 20112015, wskazać należy na ponad 40\% wzrost wartości dłużnych papierów wartościowych emitowanych przez samorządy w badanym okresie (wykres 1). Wydawać by się mogło, że wraz ze wzmiankowanym wzrostem wartości zauważalna będzie również silniejsza pozycja obligacji w strukturze zadłużenia jednostek samorządu terytorialnego. Jednak pomimo wzrostu wartości rynku obligacji komunalnych w analizowanych latach, szybsza dynamika przyrostu wartości kredytów i pożyczek spowodowała, że udział dłużnych papierów wartościowych w strukturze zadłużenia samorządów regularnie malał i kształtował się na przeciętnym poziomie ok. 7\%, przy rosnącym (ok. 93\%) udziale kredytów i pożyczek ${ }^{6}$.

\footnotetext{
${ }^{3}$ Pojęcie „obligacje komunalne" nie jest terminem prawnym, jako że ustawodawca nie zastosował go w przywołanych aktach prawnych, ale jest pojęciem nominatywnym ze względu na podmiot uprawniony do emisji obligacji (za: M. Wójcik, Obligacje przychodowe jako źródto finansowania inwestycji jednostek samorzadu terytorialnego, w: D. Zarzecki (red.), Upowszechnianie i transfer wyników badań, WN US, Szczecin 2012, s. 749).

${ }^{4}$ J. Zawora, Obligacje komunalne jako zewnętrzne źródto finansowania zadań jednostek samorzqdu terytorialnego, w: D. Zarzecki (red.), Zarzqdzanie finansami w przedsiębiorstwach $i$ jednostkach samorzadu terytorialnego, WN US, Szczecin 2014, s. 208-210.

${ }^{5}$ Art. 4 ust. 1 z 15 stycznia 2015 r. o obligacjach art. 4 ust. 1, Dz. U. 2015, poz. 238 (dalej jako: u.o.).

${ }^{6}$ Strategia zarzadzania dtugiem sektora finansów publicznych w latach 2017-2020, Ministerstwo Finansów, Warszawa 2015.
} 


\section{Wykres 1}

Wartość rynku obligacji komunalnych (pow. 365 dni) w mld zł

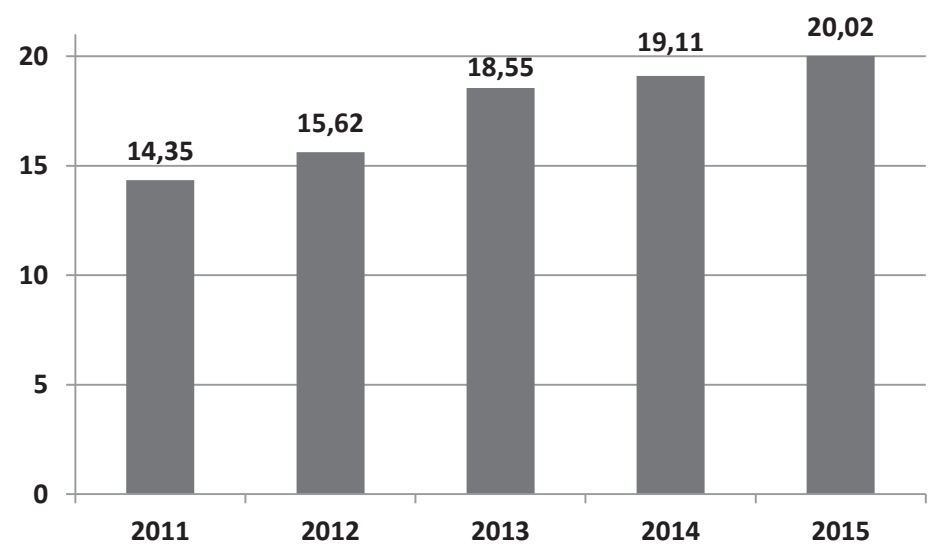

Źródło: opracowanie własne na podstawie Fitch Polska?

Określając kredyt jako dominujący instrument finansowania długu JST, należy wskazać na różnice pomiędzy nim a omawianą obligacją komunalną. Sebastian Huczek ${ }^{8}$ wskazuje na pięć podstawowych obszarów, pod kątem których należy rozpatrzyć odmienność obu instrumentów, mianowicie:

- elastyczność: jaki wpływ ma JST na kształtowanie warunków spłaty zobowiązania?

- okres zapadalności: który instrument finansowania umożliwia zastosowanie dłuższego okresu spłaty długu?

- procedura: jak wysoce kosztochłonna, czasochłonna i skomplikowana jest procedura emisji obligacji oraz zaciagnięcie kredytu?

- aspekty marketingowe: która forma finansowania może w większym stopniu przyczynić się do polepszenia wizerunku JST?

- koszt pieniądza - koszty obsługi kredytu czy emisji obligacji są niższe (który instrument jest tańszy?).

Rozpatrując powyższe kryteria $\mathrm{w}$ odniesieniu do analizowanych instrumentów finansowania JST, nie można jednoznacznie stwierdzić, wybór którego z nich jest korzystniejszy z punktu widzenia samorządu. Jednocześnie należy zaznaczyć, że w relacji do zaciągnięcia kredytu emisja obligacji umożliwia jednostce: relatywnie większą autonomię w ustalaniu warunków spłaty, dłuższy możliwy okres finansowania długu, możliwość promocji jednostki oraz ze względu na ponoszenie kosztów odsetek raz do roku ceteris paribus - niższy

7 Fitch Polska, Podsumowanie I kwartału 2012 na rynku nieskarbowych instrumentów dłużnych $w$ Polsce oraz Podsumowanie I kwartału 2016 na rynku nieskarbowych instrumentów dłuznych $w$ Polsce.

8 S. Huczek, Obligacje komunalne na rynku Catalyst, Oficjalne Wydawnictwo Giełdy Papierów Wartościowych w Warszawie SA, Warszawa 2010, s. 9-10. 
koszt obsługi obligacji ${ }^{9}$. Analizując zaś obie formy finansowania z perspektywy złożoności procedury, wskazać należy na kredyt jako względnie prostszy sposób finansowania długu jednostki. Należy jednak zaznaczyć, że emisja papierów dłużnych przez JST wyłączona jest ze stosowania Prawa zamówień publicznych, co wpływa na przyspieszenie procedury oraz daje emitentowi szersze spektrum możliwości w zakresie m.in. wyboru oferty ${ }^{10}$.

\section{PRAWNE UWARUNKOWANIA EMISJI OBLIGACJI KOMUNALNYCH W POLSCE}

Jednostki samorządu terytorialnego na mocy Konstytucji Rzeczypospolitej Polskiej ${ }^{11}$ oraz ustaw samorządowych ${ }^{12}$ posiadaja osobowość prawna, czego przejawem jest zdolność do czynności prawnych, m.in. zdolność do zaciagania zobowiązań przez emisję papierów wartościowych ${ }^{13}$.

Biorac pod uwage prawne aspekty procesu emisji obligacji (w tym komunalnych), na wstępie należy wskazać, że na gruncie obowiązującej ustawy o obligacjach wprowadzony został obowiązek sporządzania oraz udostępniania warunków emisji obligacji jako dokumentu określającego obowiązki oraz prawa zarówno emitenta, jak i obligatariusza, a także opis świadczeń wynikających z obligacji oraz sposób ich realizacji ${ }^{14}$. Ustawodawca wskazuje, iż warunki emisji sporządzane są $\mathrm{w}$ języku polskim ${ }^{15} \mathrm{w}$ formie jednolitego dokumentu, dlatego też należy przyjać, że powinny mieć formę papierowa ${ }^{16}$. Należy zatem przyjaćc, że dokument warunków emisji stanowi formalną podstawę emisji obligacji.

Artykuł 5 rozpatrywanej ustawy określa jedynie ogólną formę i treść warunków emisji. Podstawą wyszczególnienia obligatoryjnych elementów warunków emisji jest natomiast zapis art. 6, stanowiący o treści warunków emisji.

9 S. Huczek, op. cit., s. 11-14.

${ }^{10}$ D. Korenik Finansowanie inwestycji infrastrukturalnych w formule partnerstwa publiczno-prywatnego. Kwestie wybrane, w: M. Dylewski (red.), Finanse i ryzyko w kształtowaniu rozwoju regionu, Zeszyty Naukowe WSB w Poznaniu nr 41/2012, Wyd. WSB, Poznań 2012, s. 95.

11 Art. 165 Konstytucji Rzeczypospolitej Polskiej z 2 kwietnia 1997 r., Dz. U. 1997, Nr 78, poz. 483.

12 Art. 2 ust. 2 ustawy o samorządzie gminnym z 8 marca 1990 r., Dz. U. 1990, Nr 16, poz. 95; art. 2 ust. 2 ustawy o samorządzie powiatowym z 5 czerwca 1998 r., Dz. U. 1998, Nr 91, poz. 578; art. 6 ust. 2. ustawy o samorządzie województwa z 5 czerwca 1998 r., Dz. U. 1998, Nr 91, poz. 576.

${ }^{13}$ M. Musiał, Obligacje komunalne jako źródło przychodów jednostek samorzadu terytorialnego w: A. Hanusz (red.), Źródła finansowania samorządu terytorialnego, Wolters Kluwer, Warszawa 2015 , s. 416.

14 Art. 5 ust. 1 u.o.

${ }^{15}$ Ustawodawca przewiduje możliwość sporządzania warunków emisji również w języku angielskim, jednak wartość nominalna obligacji musi stanowić co najmniej 100000 euro po średnim kursie NBP z dnia emisji (art. 5 ust. 2 u.o.).

${ }^{16}$ M. Wierzbowski (red.), Ustawa o obligacjach, C. H. Beck, Warszawa 2015, s. 16-19. 
Warunki emisji powinny zawierać rodzaj obligacji. Za podstawowy podział przyjmuje się tu kryterium oznaczenia obligatariusza oraz kryterium formy dokumentu ${ }^{17}$. Należy zatem określić, jaki typ obligacji zostanie wyemitowany, tj. imienne czy na okaziciela, oraz czy będą miały formę dokumentu, czy będą to obligacje zdematerializowane.

Drugim wymaganym przez ustawę elementem jest oznaczenie emitenta. W przypadku obligacji komunalnych będą nim JST lub ich związki. Powinno się więc wskazać pełną nazwę oraz określić siedzibę jednostki lub związku jednostek w celu identyfikacji oraz uwiarygodnienia emitenta.

Emitent obligacji zobowiązany jest do wskazania w warunkach emisji adresu własnej strony internetowej. Wynika to z faktu, że szereg obowiązków informacyjnych nakładanych na emitentów wypełnianych jest za pośrednictwem Internetu. Oznacza to więc, iż ustawodawca niejako przypisuje uzyskanie statusu emitenta obligacji obowiązkowi posiadania strony internetowej.

Kolejnym obowiązkowym elementem warunków emisji jest wskazanie decyzji emitenta o emisji. Warunki emisji zawierać powinny co najmniej nazwę organu oraz numer i datę podjętej uchwały.

Niezwykle istotną część warunków emisji stanowi określenie wartości nominalnej oraz maksymalnej liczby obligacji proponowanych do nabycia. Należy zaznaczyć, że ustawodawca nie przewiduje minimalnej wartości nominalnej obligacji (wyrażonej w dowolnej walucie ${ }^{18}$ ) ani minimalnej ceny emisji obligacji. Odnosząc się zaś do wielkości emisji, określa się ją punktowo (np. 500 obligacji serii X) lub przedziałowo (np. od 1 do 500 obligacji serii X lub nie więcej niż 500 obligacji serii $\mathrm{X})^{19}$.

Immanentnym elementem warunków emisji jest opis świadczeń wynikających z obligacji. Emitent powinien wskazać wysokość świadczeń lub sposób ich ustalania, a także termin, miejsce oraz sposób ich spełnienia. Opis świadczeń winien zostać dokonany w sposób szczegółowy i jednoznaczny, gdyż pełni on rolę informacji dla obligatariusza o przysługujących mu prawach wynikających z posiadania obligacji.

Dokument warunków emisji zawierać powinien informację o planowanych do ustanowienia lub ustanowionych zabezpieczeniach bądź o braku zabezpieczenia. W praktyce JST obligacje komunalne nie sa zabezpieczone, natomiast podmiotem uwiarygodniajacym emisję jest sam emitent ${ }^{20}$.

Ostatnie z ustawowych obowiązkowych elementów warunków emisji to wskazanie miejsca i daty sporządzenia warunków emisji oraz podpisy osób upoważnionych. Na gruncie samorządu miejscem będzie miejscowość,

${ }^{17}$ J. Krzyżkowska, Art. 6. Elementy warunków emisji, w: J. Krzyżkowska et al., Ustawa o obligacjach. Komentarz praktyków, PWN SA, Warszawa 2015, s. 33.

${ }^{18}$ L. Lipiec-Warzecha, Ustawa o obligacjach. Komentarz, Wolters Kluwer Polska, Warszawa 2010, s. 117.

${ }^{19}$ R. Woźniak, Ustawa o obligacjach. Komentarz, C. H. Beck, Warszawa 2015, s. 34.

${ }^{20}$ Ł. Sobiech, Obligacje komunalne samorzqdu terytorialnego, http://samorzad.infor.pl/ [dostęp: 7.05. 2016]. 
w której znajduje się siedziba jednostki (emitenta), natomiast za datę należy przyjąc dzień podjęcia uchwały organu stanowiącego o przyjęciu warunków emisji.

Prócz obligatoryjnych części składowych warunków emisji, ustawodawca wskazuje również na szereg elementów fakultatywnych. Z punktu widzenia JST najistotniejszym postanowieniem jest zapis art. 6 ust. 2 pkt 4 u.o. stanowiący o wskazaniu celu, jeśli został określony. Jednostki samorządu terytorialnego lub ich związki będące emitentem zobligowane są do oznaczenia, a co za tym idzie - wskazania celu emisji ${ }^{21}$. Obowiązek ten jest uzasadniony w świetle przepisów prawa, gdyż środki pochodzące ze sprzedaży papierów wartościowych zgodnie z art. 5 u.o.f.p. klasyfikuje się jako środki publiczne.

Emisja obligacji komunalnych w Polsce odbywać się może na dwa sposoby, tj. w formie oferty publicznej lub propozycję nabycia obligacji $\mathrm{w}$ inny sposób ${ }^{22}$. Zgodnie z zapisami art. 3 ust. 1 ustawy o ofercie publicznej i warunkach wprowadzania instrumentów finansowych do zorganizowanego systemu obrotu oraz o spółkach publicznych ${ }^{23}$, za ofertę publiczną uznaje się udostępnienie co najmniej 150 osobom lub nieoznaczonemu adresatowi informacji o papierach wartościowych oraz warunkach ich nabycia, co stanowi podstawę w procesie decyzyjnym dotyczącym nabycia tych walorów. Należy zaznaczyć, że ustawodawca pozostawia wybór sposobu przekazania tej informacji emitentowi.

JST, decydujac się na emisję obligacji w formie oferty publicznej, zobligowana jest do zawarcia umów z firmą inwestycyjną (pośrednikiem) ${ }^{24}$ oraz z Krajowym Depozytem Papierów Wartościowych ${ }^{25}$. Ponadto wybierając formę emisji publicznej, emitent przyjmuje na siebie obowiązki wynikajace z u.o.p., tj. sporządzenie prospektu emisyjnego lub memorandum informacyjnego oraz udostępnienie go do publicznej wiadomości. Jednak przez zapis art. 7 ust. 2 pkt 2 u.o.p. obowiązek ten nie znajduje zastosowania w odniesieniu do papierów wartościowych emitowanych przez JST ${ }^{26}$. Jednakże w myśl art. 34 u.o.p. od emitenta oferującego obligacje w ofercie publicznej, który nie jest jednocześnie zobligowany do udostępnienia prospektu emisyjnego lub memorandum, wymaga się udostępnienia potencjalnemu obligatariuszowi propozycji nabycia.

JST moga również dokonać emisji obligacji w formie emisji niepublicznej (prywatnej). Sytuacja taka występuje, gdy emitent kieruje ofertę do najwyżej 149 inwestorów wskazanych imiennie. W odróżnieniu od oferty publicznej

${ }^{21}$ Art. 32 ust. 1 u.o.

22 Art. 33 ustawy z 15 stycznia 2015 r. o obligacjach, Dz. U. 2015, poz. 238.

${ }^{23}$ Dalej jako: u.o.p.

${ }^{24}$ Art. 19 ust. 1 pkt 2 ustawy z 29 lipca 2005 r. o obrocie instrumentami finansowymi, Dz. U. 2005, Nr 183, poz. 1538.

${ }^{25}$ Art. 5 ust. 4 ustawy z 29 lipca 2005 r. o obrocie instrumentami finansowymi, Dz. U. 2005, Nr 183, poz. 1538.

${ }^{26}$ M. Musiał, Obligacje komunalne jako źródto przychodów jednostek samorzqdu terytorialnego, w: A. Hanusz (red.), Źródta finansowania samorzadu terytorialnego, Wolters Kluwer, Warszawa 2015 , s. 423. 
emitent może samodzielnie przeprowadzić ofertę prywatna. Tryb ten nakłada jednak na emitenta, podobnie jak w przypadku oferty publicznej, obowiązek przygotowania i udostępnienia propozycji nabycia.

\section{CATALYST JAKO RYNEK OBROTU DŁUŻNYMI PAPIERAMI WARTOŚCIOWYMI JEDNOSTEK SAMORZĄDU TERYTORIALNEGO}

Powstały w 2009 r. rynek Catalyst to łączna nazwa dla czterech platform obrotu instrumentami dłużnymi, prowadzonych przez Giełdę Papierów Wartościowych ${ }^{27}$ oraz BondSpot ${ }^{28}$. W każdej z tych instytucji prowadzone sa dwie platformy obrotu (tab. 1): jedna w formule pozagiełdowego rynku regulowanego oraz jedna w ramach alternatywnego systemu obrotu (ASO $)^{29}$.

\section{Tabela 1}

Struktura Catalyst z uwzględnieniem podstaw prawnych regulujących rynek Catalyst

\begin{tabular}{|l|l|l|}
\hline \multicolumn{1}{|c|}{ Instytucja } & \multicolumn{1}{|c|}{ Rynek regulowany } & \multicolumn{1}{c|}{$\begin{array}{c}\text { Alternatywny } \\
\text { System Obrotu }\end{array}$} \\
\hline GPW & $\begin{array}{l}\text { Regulamin Giełdy w zakresie } \\
\text { giełdowego regulowanego } \\
\text { rynku obligacji }\end{array}$ & $\begin{array}{l}\text { Regulamin Alternatywnego } \\
\text { Systemu Obrotu prowadzo- } \\
\text { nego przez GPW w ramach } \\
\text { Catalyst }\end{array}$ \\
\hline BondSpot & $\begin{array}{l}\text { Regulamin Pozagiełdowe- } \\
\text { go Obrotu Regulowanego } \\
\text { BondSpot w zakresie regulo- } \\
\text { wanego obrotu pozagiełdowe- } \\
\text { go w ramach Catalyst }\end{array}$ & $\begin{array}{l}\text { Regulamin Alternatywnego } \\
\text { Systemu Obrotu prowadzone- } \\
\text { go przez BondSpot w ramach } \\
\text { Catalyst }\end{array}$ \\
\hline $\begin{array}{l}\text { Ustawa o obligacjach, ustawa o ofercie publicznej, ustawa o obrocie instrumentami finansowy- } \\
\text { mi, rozporządzenie Ministra Finansów w sprawie informacji bieżących i okresowych przekazy- } \\
\text { wanych przez Emitentów papierów wartościowych [...] }\end{array}$ \\
\hline
\end{tabular}

Źródło: opracowanie własne na podstawie Obligacje korporacyjne na Catalyst (2013).

Rozwiązania organizacyjno-prawne zastosowane na Catalyst dają możliwość emisji dłużnych papierów wartościowych na zorganizowanym rynku podmiotom, dla których parkiet GPW był dotychczas zamknięty, w tym również JST.

${ }^{27}$ Dalej jako: GPW.

${ }^{28}$ Rynek obligacji, http://www.gpwcatalyst.pl/, 8 maja 2016r.

29 Art. 14 i art. 78 ustawy z 29 lipca 2005 r. o obrocie instrumentami finansowymi, Dz. U. 2005, Nr 183, poz. 1538. 
Umożliwienie samorządom wprowadzenia papierów wartościowych na zorganizowany rynek nie przełożyło się jednak na duże zainteresowanie oferta Catalyst. W latach 2011-2015 obligacje komunalne wprowadzone na Catalyst stanowiły zaledwie ok. 16\% wyemitowanych obligacji komunalnych ogółem. Co więcej, w 2015 r. zauważyć można spadek tej relacji w stosunku do roku wcześniejszego. Może to oznaczać, że JST wykazują sceptyczne podejście do novum na polskim rynku papierów wartościowych, jakim jest Catalyst.

\section{Wykres 2}

Rynek obligacji komunalnych w Polsce z uwzględnieniem udziału obligacji wprowadzonych na rynek Catalyst (w mld zł)

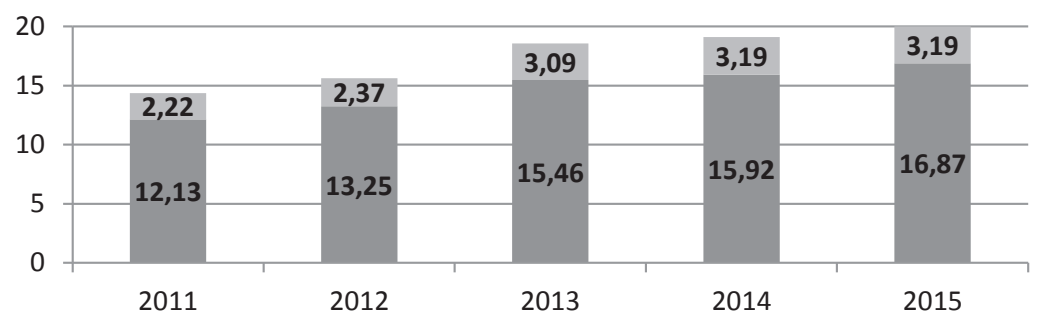

Obligacje komunalne wprowadzone na rynek Catalyst

- Obligacje komunalne poza rynkiem Catalyst

Źródło: opracowanie własne na podstawie Fitch Polska ${ }^{30}$.

Analizując katalog opłat związanych z wprowadzeniem obligacji na Catalyst (tab. 2), dostrzec można, że koszty te w głównej mierze uzależnione są od ilości i wielkości serii, okresu zapadalności, wysokości oprocentowania oraz częstotliwości wypłaty odsetek. Zatem odpowiednia strukturyzacja emisji, tj. ograniczenie liczby serii w danej emisji, może przyczynić się do znacznego obniżenia kosztów wprowadzenia obligacji na Catalyst. Symulacja przeprowadzona na stronie internetowej www.gpwcatalyst.pl pozwala zauważyć, że przy tych samych parametrach emisji emitent może zaoszczędzić nawet do 60\% wysokości opłat, emitując obligacje w jednej serii w relacji do wartości kosztów emisji obligacji w pięciu seriach.

${ }^{30}$ Fitch Polska, Podsumowanie I kwartału 2012 na rynku nieskarbowych instrumentów dłużnych w Polsce, Fitch Polska; Podsumowanie I kwartału 2016 na rynku nieskarbowych instrumentów dtużnych w Polsce. 
Tabela 2

Koszty wprowadzenia obligacji na Catalyst

\begin{tabular}{|c|c|}
\hline Instytucja & Rodzaj i wysokość kosztu \\
\hline $\begin{array}{l}\text { Krajowy Depozyt Papierów } \\
\text { Wartościowych (KDPW) }\end{array}$ & $\begin{array}{l}\text { - } \text { Opłata za uczestnictwo - } 2000 \mathrm{zł} \\
\text { - } \text { Opłata za nadanie kodu dla serii - } 500 \mathrm{zł} \\
\text { - } \text { Opłata za utrzymywanie kodu - } 200 \mathrm{zł} \text { rocznie } \\
\text { - } \text { Opłata z tyt. rejestracji (dot. każdej serii) - 0,0075\% warto- } \\
\quad \text { ści rynkowej obligacji (min. } 2000 \mathrm{zł,} \mathrm{max.} 50000 \mathrm{zł}) \\
\text { - } \text { Opłata z tyt. obsługi wypłaty odsetek i wykupu - 0,04\% war- } \\
\quad \text { tości przekazywanych kwot (min. } 500 \mathrm{zł,} \mathrm{max.} 4000 \mathrm{zł)}\end{array}$ \\
\hline $\begin{array}{l}\text { Giełda Papierów } \\
\text { Wartościowych } \\
\text { w Warszawie SA (GPW), } \\
\text { BondSpot SA }\end{array}$ & $\begin{array}{l}\text { - W przypadku pierwszej emisji (serii) o wartości nominalnej } \\
\text { do } 10000000 \mathrm{zł} \text {, opłata za wprowadzenie do obrotu wynosi } \\
0,01 \% \text { wartości nominalnej danej emisji (serii) oraz } 100 \mathrm{zł} \\
\text { za każdy planowany rok terminu realizacji praw z dłużnych } \\
\text { instrumentów finansowych danej emisji (serii), jednak nie } \\
\text { mniej niż } 1000 \mathrm{zł} \\
\text { - Od części przekraczającej kwotę } 100000000 \text { zł wartości no- } \\
\text { minalnej danej emisji (serii) 0,0075\% wartości nominalnej } \\
\text { danej emisji (serii), oraz } 300 \text { zł za każdy planowany rok do } \\
\text { terminu realizacji praw z dłużnych instrumentów finanso- } \\
\text { wych danej emisji (serii), jednak nie mniej niż } 3000 \text { zł i nie } \\
\text { więcej niż } 30000 \mathrm{zł}\end{array}$ \\
\hline
\end{tabular}

Źródło: opracowanie własne na podstawie www.gpwcatalyst.pl.

W'́ród JST, które w ciagu analizowanych pięciu lat zdecydowały się na wprowadzenie wyemitowanych obligacji do zorganizowanego systemu obrotu, przeważaja gminy, natomiast biorąc pod uwagę wartość emisji, to miasta na prawach powiatu ${ }^{31}$ dominuja wśród pozostałych jednostek ${ }^{32}$ (wykres 2).

Analizując strukturę podmiotową nabywców obligacji komunalnych, należy zwrócić uwagę na fakt, że w praktyce gospodarczej najczęstszymi nabywcami obligacji emitowanych przez JST są banki ${ }^{33}$, których udział w strukturze nabywców obligacji komunalnych w Polsce stanowi ok. 90\% ${ }^{34}$. Z punktu widzenia banków obligacje komunalne stanowią istotny (drugi pod względem wartości) nieskarbowy instrument dłużny w portfelu własnym banków oraz portfelach ich klientów, z procentowym udziałem wynoszącym niespełna $34 \%$ portfela.

\footnotetext{
31 m.n.p.p.

32 „Biuletyn Statystyczny Catalyst” 2011, 2012, 2013, 2014, 2015.

${ }^{33}$ Ł. Sobiech, Obligacje komunalne samorzadu terytorialnego,http://samorzad.infor.pl/temat_dnia/387375,Obligacje-komunalne-samorzadu-terytorialnego.html, 9 maja 2016.

${ }^{34}$ Dane na 29 lutego 2016 r. - Fitch Polska, Podsumowanie I kwartału 2016 na rynku nieskarbowych instrumentów dłużnych w Polsce.
} 


\section{Wykres 3}

Obligacje komunalne obecne na rynku Catalyst w latach 2011-2015 według liczby emitentów

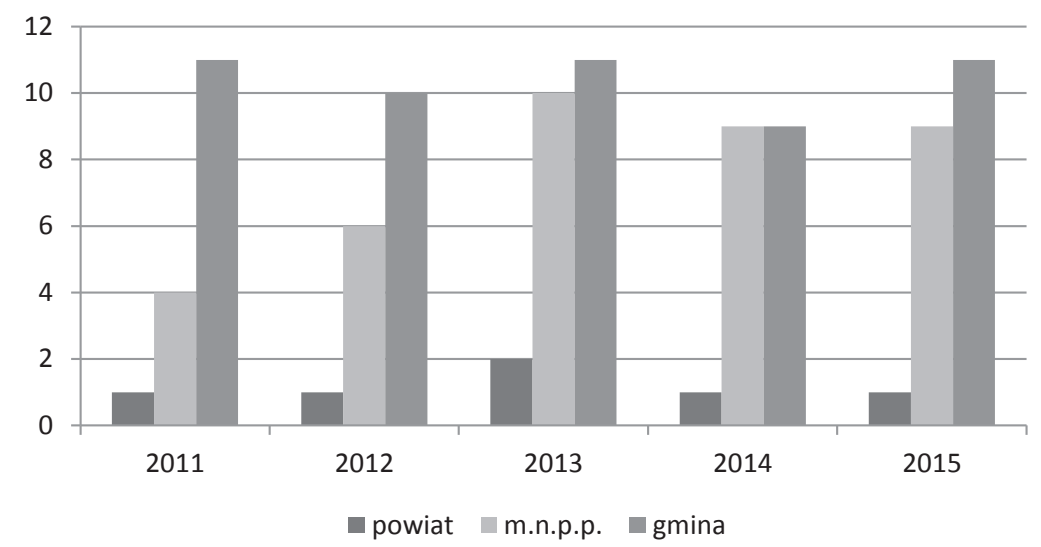

Źródło: opracowanie własne na podstawie „Biuletyn Statystyczny Catalyst” 2011, 2012, 2013, 2014, 2015.

Wskazanie na banki jako głównych nabywców obligacji komunalnych skłania do rozróżnienia zaciagnięcia kredytu przez JST oraz wyemitowania przez nią obligacji w całości objętych przez bank, ponieważ pozornie obie omawiane formy finansowania samorządów nie różnią się od siebie, ze względu na instytucję wierzyciela, którą w obu przypadkach pełni bank. Należy tutaj wskazać na swobodę emitenta w zakresie kształtowania warunków spłaty jako zasadniczy element różnicujący oba instrumenty.

\section{Wykres 4}

Stopy oprocentowania bazujące na wskaźnikach WIBOR3M i WIBOR6M (z uwzględnieniem marży 2pp) w latach 2011-2016

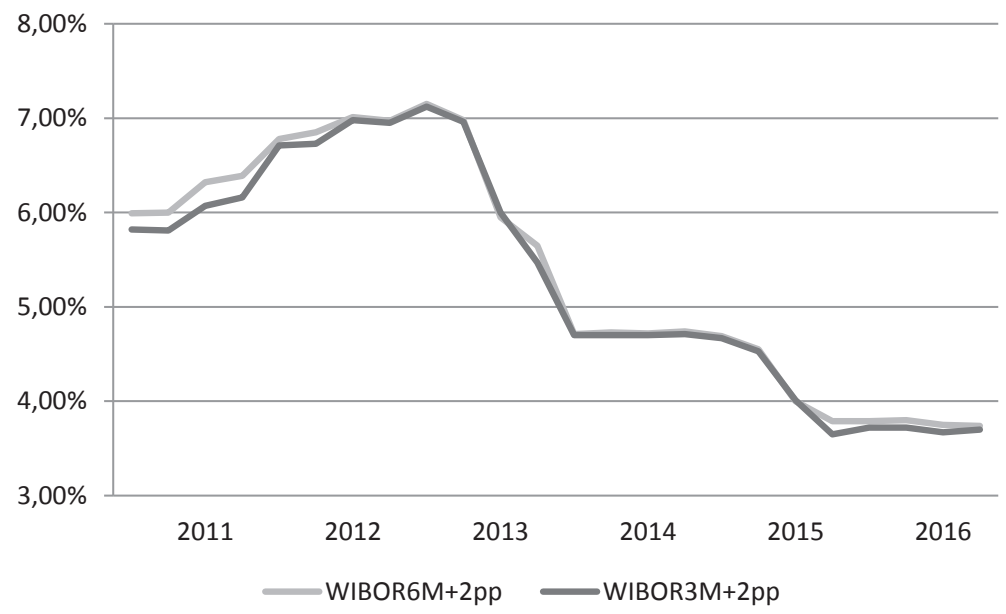

Źródło: opracowanie własne. 
Biorąc pod uwagę zależność oprocentowania obligacji komunalnych od stopy WIBOR6M oraz fakt, że oprocentowanie długoterminowych kredytów dla JST opiera się zazwyczaj na WIBOR3M, można zauważyć, iż oprocentowanie kredytu dla jednostki samorządu terytorialnego w ww. okresie było niższe od oprocentowania obligacji. Rozpatrując jednak wielkości przepływów związanych z emisją obligacji oraz zaciagnięciem kredytu, wskazać należy na różny sposób obliczania wypłaty oprocentowania. W przypadku obligacji okres odsetkowy ustala się zazwyczaj na pół roku, a oprocentowanie wypłacane jest według procentu prostego, gdzie podstawą naliczenia jest wartość nominalna obligacji. W kredycie natomiast najczęstszym sposobem naliczania odsetek jest tzw. procent składany. Dlatego też okres kapitalizacji odsetek uznać należy za czynnik decydujący o uznaniu kosztów obsługi emisji obligacji komunalnych za tańsze od kosztów obsługi kredytu, nawet przy uwzględnieniu kosztów wprowadzenia obligacji na rynek Catalyst ${ }^{35}$.

Chcąc mówić o strukturze podmiotowej emitentów samorządowych, rozpatrując jednocześnie korzyści wynikające z obecności na rynku Catalyst, warto przyjrzeć się jednostkom mniejszym. Najmniejszą JST pod względem liczby ludności, której obligacje notowane są w ramach Catalyst, jest leżąca w województwie ślaskim, powiecie częstochowskim ${ }^{36}$, liczacca niespełna 11 tys. mieszkańców ${ }^{37}$ gmina wiejska Konopiska. Uchwałą rady gminy Konopiska z 14 kwietnia 2010 r. zadecydowano o wyemitowaniu w trybie oferty niepublicznej 5900 obligacji w 5 seriach na łączna sumę $5,9 \mathrm{mln}$ zł w celu budowy gminnej hali sportowej wraz z zapleczem. W tym samym dniu moca kolejnej uchwały podjęto decyzję o wprowadzeniu obligacji komunalnych do zorganizowanego systemu obrotu. Główną przesłanką do podjęcia decyzji o emisji obligacji przez ww. jednostkę było kryterium kosztu pozyskania środków. Zarówno w projektach budżetów, jak i uchwałach budżetowych wielokrotnie wskazuje się właśnie na emisję obligacji jako tańszą (choć bardziej pracochłonna) formę pozyskania finansowania jednostki ${ }^{38}$. Należy przy tym wskazać, że Gmina Konopiska zdecydowała się wprowadzić na rynek Catalyst 550 obligacji serii A1 (5-letnie) oraz 2200 obligacji serii A2 (6-letnie) na łączna wartość $2,75 \mathrm{mln}$ zł (wartość nominalna jednej obligacji wyniosła $1000 \mathrm{zł}$ ). Wprowadzone obligacje oprocentowane zostały według stopy zmiennej określonej jako wartość wskaźnika WIBOR6M powiększonej o 2pp marży. Przyjęto ponadto półroczny okres odsetkowy ${ }^{39}$.

Wskazane serie obligacji, które wprowadzone zostały do zorganizowanego systemu obrotu, wyemitowane zostały w trybie oferty niepublicznej, co znaczy, że emisja skierowana była do nie więcej niż 149 inwestorów krajowych i zagranicznych. W rzeczywistości wszystkie obligacje gminy Konopiska wprowadzone na Catalyst objęte zostały przez PKO Bank Polski.

35 S. Huczek, op. cit., s. 14.

36 Zob. http://www.bip.konopiska.akcessnet.net [dostęp: 22.05.2015].

${ }_{37}$ Strategia Rozwoju Gminy Konopiska na lata 2016-2020, s. 14.

38 Uchwała nr 30/VI/2015 Rady Gminy Konopiska z 29 stycznia 2015 r. w sprawie uchwalenia budżetu Gminy Konopiska na 2015 rok.

39 Dokument Informacyjny Gmina Konopiska. 
Instrumenty dłużne mogą być obecne na Catalyst nie tylko przez skierowanie emisji do zorganizowanego obrotu, lecz również przez otrzymanie autoryzacji dla emisji, bez ubiegania się o dopuszczenie/wprowadzenie do obrotu na jakimkolwiek z subrynków ${ }^{40}$. Oznacza to, że emitent rejestruje walory w publicznym systemie informacyjnym Catalyst i zobowiązuje się do regularnego raportowania zgodnie z obowiązującymi na rynku regulacjami.

Autoryzacja obligacji komunalnych oznacza dla JST liczne korzyści wynikające z obecności na zorganizowanym rynku, nie wymaga jednak spełnienia obowiązków nakładanych na podmioty, których papiery wartościowe zostały wprowadzone do obrotu. Warto również dodać, że o autoryzację ubiegać się można zarówno dla nowej emisji, jak i dla papierów będących już przedmiotem obrotu, co jest szczególnie istotne dla JST, które wyemitowały już obligacje, a z biegiem czasu wyraziłyby chęć zarejestrowania emisji w systemie informacyjnym Catalyst. Autoryzacja nie cieszy się jednak zainteresowaniem samorządów. O ile w $2011 \mathrm{r}$. autoryzowanych było 18 serii obligacji emitowanych przez pięć jednostek, o tyle na koniec $2015 \mathrm{r}$. autoryzację posiadały jedynie 3 serie obligacji komunalnych wyemitowanych przez trzy jednostki, mianowicie Tczew, Turek oraz Ząbii ${ }^{41}$.

Zarówno skierowanie obligacji do zorganizowanego obrotu, jak również uzyskanie autoryzacji wyemitowanych papierów dłużnych bez ubiegania się o dopuszczenie do obrotu wymusza na samorządzie prowadzenie przejrzystej polityki informacyjnej, co przekłada się na jego wiarygodność rynkową. Co więcej, jest to niezwykle istotny element promocji jednostki, mogacy wpłynąć w przyszłości na pozyskanie kapitału na korzystniejszych warunkach ${ }^{42}$.

Analiza dokumentów emitentów obligacji komunalnych zamieszczonych na witrynie internetowej Catalyst pozwala zauważyć, że w przeważającej części przypadków cel emisji określony został przez JST ogólnie, jako finansowanie deficytu oraz spłata zobowiązań z tytułu kredytów, pożyczek i emisji papierów wartościowych. Niektóre jednostki wskazywały w warunkach emisji bardziej sprecyzowany cel. Przykładami takich jednostek sa m.in. omawiana gmina Konopiska (budowa hali sportowej), gmina Ustronie Morskie (inwestycje infrastrukturalne) czy miasto Rybnik (finansowanie pomostowe inwestycji infrastrukturalnych). Oznacza to, że Catalyst jest dla JST nie tylko rynkiem pozyskiwania środków na finansowanie deficytu i refinansowanie zadłużenia, lecz również źródłem pozyskania funduszy na inwestycje rozwojowe.

Oprocentowanie obligacji komunalnych na Catalyst w badanym okresie oscylowało w granicach od ok. 3\% do 7\% i uzależnione było najczęściej od wysokości WIBOR6m. Wysokość oprocentowania obligacji komunalnych jest jedną z niższych spośród instrumentów notowanych na Catalyst (np. wysokość oprocentowania obligacji East Pictures SA wyniosła 17\%) jednak obligacje komunalne należą do najbezpieczniejszych papierów wartościowych.

${ }^{40}$ S. Huczek, Obligacje komunalne na rynku Catalyst, Oficjalne Wydawnictwo Giełdy Papierów Wartościowych, Warszawa 2009, s. 25.

${ }^{41}$ „Biuletyn Statystyczny Catalyst” 2015.

${ }^{42}$ J. Gliniecka (red), Finanse publiczne jednostek samorzqdu terytorialnego, CeDeWu, Warszawa 2014, s. 191. 
Biorąc pod uwagę okres zapadalności, obligacje komunalne wyróżniają się na tle pozostałych dłużnych instrumentów notowanych na Catalyst stosunkowo długim terminem wykupu, np. okres zapadalności obligacji miasta Siedlce wyemitowanych w 2013 r. wynosi 18 lat, tzn. zostana one wykupione w 2033 r. Średni okres zapadalności obligacji komunalnych obecnych na Catalyst jest jednym z najdłuższych (dla porównania okres zapadalności obligacji przedsiębiorstw notowanych na Catalyst wynosi ok. 3 lat).

\section{PODSUMOWANIE}

Obligacje komunalne w Polsce stanowią istotny element struktury zadłużenia jednostek samorządu terytorialnego. Jednak pomimo rokrocznych wzrostów nominalnej wartości rynku obligacji komunalnych dynamika wzrostu wartości rynku kredytów i pożyczek udzielanych samorządom jest szybsza, co powoduje regularny spadek udziału obligacji komunalnych w przedmiotowej strukturze zadłużenia jednostek samorządu terytorialnego.

W latach 2011-2015 odnotowywano rokroczny nominalny wzrost wartości obligacji komunalnych wprowadzonych na rynku Catalyst. Przeprowadzona analiza pozwala na sformułowanie wniosku, iż obecność na rynku regulowanym JST będących emitentami obligacji nie jest zarezerwowana wyłącznie dla relatywnie dużych jednostek. Świadczy o tym opisywany przykład gminy wiejskiej Konopiska, jak również fakt, że w badanym okresie na rynku Catalyst notowane były obligacje wyemitowane przez gminy stosunkowo niewielkie, m.in. Ustronie Morskie, Barcin czy Brodnica.

Obserwując rynek Catalyst pod kątem emitentów będących JST, dostrzec można niewielkie wahania liczby emitentów w ostatnich trzech latach analizowanego okresu. Świadczy to o niewielkim zainteresowaniu emitentów wprowadzaniem obligacji do zorganizowanego obrotu, czego wyrazem była sytuacja z 2015 r., w którym nie wprowadzono do obrotu na Catalyst żadnych obligacji komunalnych ${ }^{43}$. Pozagiełdowy rynek regulowany Catalyst powstał głównie z myślą o jednostkach samorządu terytorialnego oraz przedsiębiorstwach. O ile obligacje korporacyjne stanowią najintensywniej rozwijający się element rynku Catalyst ${ }^{44}$, o tyle segment obligacji komunalnych znalazł się w impasie. Spowolnienie na rynku obligacji komunalnych spowodowane może być przez m.in.: obawy władz samorządowych przed zaciaganiem długu na rynku czy dostęp do alternatywnych źródeł finansowania (np. rosnącą wartością realizacji programów w ramach formuły partnerstwa publiczno-prywatnego - PPP $)^{45}$.

${ }^{43}$ Marże procentowe obligacji na Catalyst w 2015 r., https://www.globalrating.pl/marze-procentowe-obligacji-na-catalyst-w-2015-r.html [dostęp: 25.05.2016].

${ }^{44}$ Rynek obligacji Catalyst szansa na finansowanie dtużne firm $i$ samorzadów, http://www. wspolnota.org.pl/aktualnosci/aktualnosc/rynek-obligacji-catalyst-szansa-na-finansowanie-dluzne-firm-i-samorzadow/ [dostęp: 25.05.2016].

${ }^{45}$ K. Sobiech-Grabka (red.), Przeglad przedsiębiorstw na rynku PPP $w$ Polsce, Centrum Partnerstwa Publiczno-Prywatnego, Warszawa 2015, s. 24. 
Od 2001 r. zadłużenie samorządów w Polsce regularnie rosło z poziomu niespełna 11 mld zł, by na koniec 2015 r. wynieść ponad 72 mld złㄴ. Eskalacja zadłużenia samorządów powoduje, że rola pozacenowych aspektów pozyskiwania finansowania przez JST staje się marginalna, skutkiem czego, najistotniejszym kryterium wyboru formy finansowania staje się kryterium kosztowe, co biorac pod uwagę relatywnie wysokie koszty wprowadzenia obligacji na rynek Catalyst, sprawia, że korzystanie z pozagiełdowego rynku regulowanego bywa coraz częściej nieopłacalne. Dlatego w celu zachęcenia JST do plasowania emisji na Catalyst powinny zostać obniżone opłaty za wprowadzenie obligacji, a także należy zmniejszyć wysokość opłat dla jednostek, które korzystały wcześniej z oferty Catalyst.

mgr Jakub Zieliński

Uniwersytet Ekonomiczny w Poznaniu

jakub.zielinski@ue.poznan.pl

\section{MUNICIPAL BONDS IN THE CATALYST MARKET \\ BETWEEN 2011 AND 2015}

\section{Sum mary}

The municipal bonds market is presented against the background of the situation in the trading market for debt securities in Poland between 2011 and 2015. Since 2001 a systematic increase in the debt of local governments has been observed, which consequently forced local governments to seek alternative sources of founding such as bonds. The legal aspects arising in connection with the issuance of municipal bonds have been analysed. The situation in the trading market for debt securities in the years 2011-2015 leads to the conclusion that the non-price aspects of financing have become rather irrelevant. This, in turn, shows that municipal bonds available through the OTC Market Trading are no longer always an advantageous solution for local governments.

${ }^{46}$ Ministerstwo Finansów, Zadtużenie Sektora Finansów Publicznych IVkw/2015. 